\title{
Pressure compensation by a floppy disk in a sprinkler with rotation by centrifugal action
}

\section{Disco flexível como compensador de pressão em aspersor com rotação por ação centrífuga}

\author{
Vinicius Mendes Rodrigues de Oliveira ${ }^{1 *}$; João Alberto Fischer Filho ${ }^{2}$; \\ José Renato Zanini ${ }^{3}$; Luis César Dias Drumond ${ }^{4}$
}

\begin{abstract}
Water wastage is a great concern worldwide. Water is effectively utilized by using equipment and systems that have more uniform water distribution. The objective of this study was to evaluate the performance of the FR Super 10 sprinkler with a pressure compensator under different pressures, spacing, and installation heights. The tests were performed in the laboratory, and pressure was controlled with two gauges calibrated with a mercury column. The distribution uniformity was measured using the Christiansen uniformity coefficient (CUC) and distribution uniformity coefficient (CUD). Four spray nozzles were utilized for the Super 10 sprinkler, at two heights $(0.6$ and $1.2 \mathrm{~m})$, six pressures $(25,30$, $35,40,45$, and $\left.50 \mathrm{~m} \mathrm{H}_{2} \mathrm{O}\right)$, and six spacings $(9 \times 9,9 \times 10,10 \times 10,9 \times 12,10 \times 12$, and $12 \times 12 \mathrm{~m})$. The blue, yellow, and red nozzles presented self-compensating features and the green nozzle was not fully self-compensating. The manufacturing coefficients of variations were lower in the nozzles with smaller apertures (blue and yellow) compared to those with larger apertures. Increasing the sprinkler height provided better water distribution uniformity and a better radial distribution profile, lowering the application rate near the sprinkler. Since this sprinkler compensates for pressure changes, pressure did not influence the sprinkler range.
\end{abstract}

Key words: CATCH-3D. CUC. CUD. Self-compensating. Water saving.

\section{Resumo}

Atualmente há grande preocupação com o desperdício de água. Utilizando equipamentos e sistemas que possuem maior uniformidade de distribuição de água, obtém-se melhor aproveitamento da água aplicada. O objetivo deste trabalho foi avaliar o desempenho do aspersor modelo FR Super $10 \mathrm{com}$ compensador de pressão, sob diferentes pressões de trabalho, espaçamentos e alturas de instalação. Os testes foram realizados em laboratório, controlando-se a pressão com dois manômetros previamente calibrados com coluna de mercúrio e a uniformidade de distribuição avaliada utilizando-se o Coeficiente de Uniformidade de Christiansen (CUC) e o Coeficiente de Uniformidade de Distribuição (CUD). Foram utilizados quatro bocais do aspersor Super 10, duas alturas $(0,6$ e 1,2 m), seis pressões $(25,30$, $35,40,45$ e 50 m.c.a.) e seis espaçamentos (9x9, 9x10, 10x10, 9x12, 10x12 e 12x12 m). Os bocais azul, amarelo e vermelho apresentaram características autocompensantes e o bocal verde não foi totalmente autocompensante, os coeficientes de variação de fabricação $(\mathrm{CV})$ foram maiores nos bocais com menor

1 Discente de Doutorado em Engenharia Agrícola, Departamento de Engenharia Agrícola, Universidade Federal de Viçosa, UFV, Viçosa, MG, Brasil. E-mail: viniciusmro91@gmail.com

2 Discente de Doutorado em Agronomia, Ciência do Solo, Departamento de Engenharia Rural, Universidade Estadual Paulista, UNESP, Jaboticabal, SP, Brasil. E-mail: joaofischer16@gmail.com

3 Prof. Dr., Departamento de Engenharia Rural, UNESP, Jaboticabal, SP, Brasil. E-mail: jrzanini@fcav.unesp.br

4 Prof. Dr., UFV, Rio Paranaíba, MG, Brasil. E-mail: irriga@ufv.br

Author for correspondence 
abertura (azul e amarelo) comparados com os bocais de maior abertura. Aumentando-se da altura de instalação do aspersor, de 0,6 para $1,2 \mathrm{~m}$, proporciona melhoria da uniformidade e do perfil radial de distribuição, diminuindo a intensidade de aplicação próximo do aspersor. Como este aspersor possui compensador de pressão a variação de pressão não influenciou no raio de alcance do aspersor.

Palavras-chave: Autocompensante. CATCH-3D. CUC. CUD. Economia de água.

\section{Introduction}

One of the challenges faced by irrigation researchers, is how to minimize water loss related to the hydraulic installation and distribution of water from the emitters. Hence, one of the strategies used to reduce water loss in irrigation systems is the development of equipment that uses water with greater efficiency.

Some factors should be evaluated to define the best installation conditions for a sprinkler system, including the installation height and spacing between sprinklers. The catalogues provided by the manufacturers often provide incomplete information, especially regarding the performance of the sprinkler systems under the conditions of different spacing and height.

Gomide (1978) evaluated how the height of the sprinkler riser pipe affected the uniformity of water distribution and concluded that an increase in height, in the absence of wind, increases uniformity. Another factor that affects the performance of the sprinkler system is the working pressure. The majority of sprinkler systems present great variation in flow when the irrigation system is not maintained under a constant working pressure. Pressure variations along the irrigation system hamper the uniformity of the flow rate applied by the equipment. Installation of pressure regulating valves is commonly used to control these variations. Oliveira and Figueiredo (2007) evaluated the influence of pressure regulating valves on the uniformity of water application and concluded that their use reduces variation in flow between the sides, and promotes a $12 \%$ economy of water. In addition, when the terrain is irregular, pressure-regulating valves ensure a greater uniformity of application, thereby increasing the value of the Christiansen coefficient of uniformity (CUC) and the coefficient of uniformity of distribution (CUD).

In addition to the use of pressure regulating valves to promote greater flow uniformity, some emitters have pressure compensators, which guarantee similar flow along the rows, eliminating the problems of pressure variation (ZANINI et al., 1998).

The installation conditions and equipment used define the distribution of the water irrigation system. The uniformity of distribution is an efficient way to evaluate water distribution by irrigation systems (CLEMMENS; MOLDEN, 2007). Two coefficients are often used to determine uniformity: the CUC (CHRISTIANSEN, 1942) and the CUD. CUC is used to measure the spatial variability of water depth applied by irrigation systems, which is the main parameter determining the uniformity of application (MARTINS et al., 2012). The CUD measures the lowest quarter depth of the total area divided by the average depth applied (CRIDDLE et al., 1956). According to Alvarez et al. (2004), the greater the uniformity of water application, the higher the economic yield of the crop, which will consume lower levels of water, energy, and fertilizers, with gain in productivity.

Based on the hypothesis that the installation position and the modernity of sprinkler manufacture influence the distribution of water in irrigation systems, the objective of this study was to evaluate the performance of the FR Super 10 sprinkler model with pressure compensator under different working pressure, row spacing, and installation height.

\section{Material and Methods}

The experiment was conducted in the Laboratory of Hydraulics and Irrigation, in a closed environment 
without wind influence, by using a rotating compact plastic sprinkler. Rotation was caused by a sphere moved by centrifugal action, with bayonet type nozzles (blue, yellow, green, and red) and a jet angle of $25^{\circ}$. The FR Super 10 model (Flow Regulated) sprinkler is manufactured by NaanDanJain and is intended for cultivation in greenhouses, open fields, and in landscaping. The sprinkler has a pressure compensator composed of a floppy disk (Figure 1). This floppy disk is a membrane that fits inside the sprinkler to decrease or release the passage of water through an opening, due to the pressure in the system. When the pressure is high, the membrane fits next to the opening, thereby increasing the loss of load and decreasing the flow. When the pressure is at the lower limit of the compensation range, the membrane moves from the opening without decreasing the flow. This flexible disk maintains flow at pressures of 30 to $50 \mathrm{~m} \mathrm{H}_{2} \mathrm{O}$; performance data are presented in Table 1.

Figure 1. Sprinklers with colored nozzles, spheres that cause rotation by centrifugal force, and pressure compensating membranes.

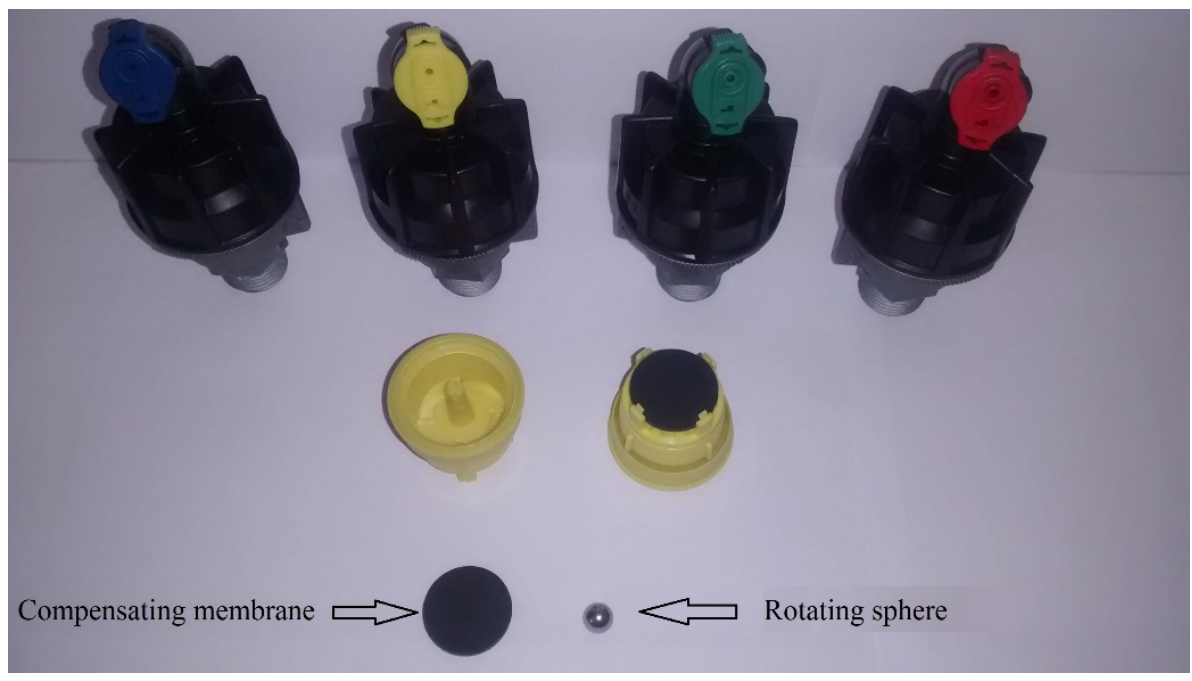

Table 1. Sprinkler performance at $0.6 \mathrm{~m}$ height and $25 \mathrm{~m} \mathrm{H}_{2} \mathrm{O}$ pressure without a pressure regulator, and 30 to $50 \mathrm{~m}$ $\mathrm{H}_{2} \mathrm{O}$ with a pressure regulator, in accordance with the manufacturer's catalogue.

\begin{tabular}{cccc}
\hline Nozzle & $\begin{array}{c}\text { Flow rate } \\
\left(\mathrm{L} \mathrm{h}^{-1}\right)\end{array}$ & $\begin{array}{c}\text { Diameter of wetness } \\
(\mathrm{m})\end{array}$ & Recommended spacings $(\mathrm{m} \times \mathrm{m})$ \\
\hline Blue & 360 & 18 & $9 \times 9 ; 9 \times 10 ; 10 \times 10$. \\
Yellow & 450 & 20 & $9 \times 9 ; 9 \times 10 ; 10 \times 10 ; 9 \times 12 ; 10 \times 12 ; 12 \times 12$. \\
Green & 550 & 20 & $9 \times 9 ; 9 \times 10 ; 10 \times 10 ; 9 \times 12 ; 10 \times 12 ; 12 \times 12$. \\
Red & 670 & 21 & $9 \times 9 ; 9 \times 10 ; 10 \times 10 ; 9 \times 12 ; 10 \times 12 ; 12 \times 12$. \\
\hline
\end{tabular}

Flow measurements were made with the aid of catch cans, without affecting the sprinkler speed. The total volume of water flow in $3 \mathrm{~min}$ at six working pressures $(25,30,35,40,45$, and 50 $\mathrm{m}_{2} \mathrm{O}$ ), was collected in plastic containers and weighed, with four sprinklers taken at random from the manufacturer's production line. Thus, the coefficients of variation (CV) were calculated, and standard equations adjusted to classify the flow. The CVs were classified according to the method described by Solomon (1979), ABNT (2000), and ASAE (1999). 
Water distribution was assessed using the radial method (ABNT, 2000) by spacing catch cans 0.5 $\mathrm{m}$ apart, forming a radius from the sprinkler at a location protected from the wind effect, during 1 hour. The cans had a conical geometric shape, with the top diameter of $0.08 \mathrm{~m}$ and height of $0.102 \mathrm{~m}$. Graduated cylinders were used to measure the volume during the experiment. The sprinklers were installed at heights of $0.6 \mathrm{~m}$, as recommended by the manufacturer, and $1.2 \mathrm{~m}$ above the top of the cans.

Pressure was controlled using two Bourdon tube pressure gauges, previously calibrated in a laboratory, with a mercury column manometer, one coupled at the base of the sprinkler and the other at the pump outlet. The pressure was adjusted with slide and needle valves installed at the pump outlet, and in the sprinkler riser pipe, respectively.

The CUC and CUD were calculated using the CATCH 3D program, version 4.45 (ALLEN, 1992), for the six row spacings provided in the manufacturer's catalog $(9 \times 9,9 \times 0,10 \times 10,9 \times$ $12,10 \times 12$, and $12 \times 12 \mathrm{~m}$ ). The CUC and CUD coefficients were classified as shown in Table 2.

Table 2. Classification of the combined CUC and CUD values for spraying systems.

\begin{tabular}{ccc}
\hline Classification & CUC $(\%)$ & CUD (\%) \\
\hline Excellent & $>90$ & $>84$ \\
Good & $>80-90$ & $>68-84$ \\
Average & $>70-80$ & $>52-68$ \\
Poor & $60-70$ & $36-52$ \\
Unacceptable & $<60$ & $<36$ \\
\hline
\end{tabular}

Source: MANTOVANI (2001).

The CUC and CUD values were subjected to analysis of variance $(\mathrm{P}<0.05)$ for the height and pressure variables in a double factorial scheme, analyzing six pressures $\times$ two heights, and subsequently, the means were compared by Tukey's test $(\mathrm{P}<0.05)$.

\section{Results and Discussion}

Table 3 shows the variations of flow indicated by the manufacturer compared to the flow rates obtained during the tests. For the blue and yellow nozzles, this variation was higher (10.21 and $11.59 \%$, respectively) than the maximum acceptable limit (5\%) (ABNT, 2000) only at the lowest pressure $\left(25 \mathrm{~m} \mathrm{H}_{2} \mathrm{O}\right)$. For the green nozzle, the variation exceeded $5 \%$ at pressures of 25,35 , and $50 \mathrm{~m} \mathrm{H}_{2} \mathrm{O}$, while the variation exceeded $5 \%$ for the red nozzle at 25 and $40 \mathrm{~m} \mathrm{H}_{2} \mathrm{O}$.
Between 30 and $50 \mathrm{~m} \mathrm{H}_{2} \mathrm{O}$, the sprinklers self-compensate, according to the manufacture's catalogue. The blue and yellow nozzles presented $\mathrm{CV}$ values within this compensation range, which were below the $10 \%$ variation recommended by ABNT (2000), showing that the flow indicated by the manufacturer presented acceptable variations when evaluated. Variations above 5\% occurred for the green and red nozzles at pressures within the compensation range. These variations in flow, together with the field installation conditions, such as topography, which influence the sprinkler pressure, can cause higher variations than are found in the laboratory (OLIVEIRA; FIGUEIREDO, 2007).

The CV was classified (Table 4) as having "good" uniformity according to ABNT (2000) for all pressures in all nozzles. The nozzles had a CV ranging from 2.7 to $5.5 \%, 2$ to $7.9 \%$, and 1 to $1.8 \%$ for blue, yellow, and green, and red, respectively. 
According to the classification, proposed by Solomon (1979) and ASAE (1999) (Table 3), the green and red nozzles presented excellent $\mathrm{CVs}$ at all pressures. The blue nozzle presented an excellent $\mathrm{CV}$ at the lower pressure $\left(25 \mathrm{~m} \mathrm{H}_{2} \mathrm{O}\right)$ and average CVs at the other pressures. The yellow nozzle had an excellent $\mathrm{CV}$ at 25, 30, and $35 \mathrm{~m} \mathrm{H}_{2} \mathrm{O}$, an average $\mathrm{CV}$ at $40 \mathrm{~m} \mathrm{H}_{2} \mathrm{O}$, and poor $\mathrm{CV}$ at 45 and $50 \mathrm{~m} \mathrm{H}_{2} \mathrm{O}$. According to Martins et al. (2015), there is a positive linear relationship between pressure and $\mathrm{CV}$, which was observed with the blue, yellow, green, and red nozzles. It is important that sprinklers present low $\mathrm{CV}$ values, because the uniformity of sprinkler manufacture also influences the uniformity of water distribution (KELLER; KARMELI, 1974). As the pressure increased, the classification of the blue and yellow nozzles went from excellent to poor (SOLOMON, 1979; ASAE, 1999).

Table 3. Comparison between the flow rates obtained and those reported by the manufacturer, for blue, yellow, green, and red nozzles.

\begin{tabular}{|c|c|c|c|c|}
\hline Nozzle & Pressure $\left(\mathrm{m} \mathrm{H}_{2} \mathrm{O}\right)$ & $\begin{array}{l}\text { Obtained flow } \\
\left(\mathrm{L} \mathrm{h}^{-1}\right)\end{array}$ & $\begin{array}{l}\text { Reported flow } \\
\left(\mathrm{L} \mathrm{h}^{-1}\right)\end{array}$ & $\begin{array}{c}\text { Variation* } \\
(\%)\end{array}$ \\
\hline \multirow{6}{*}{ Blue } & 25 & 323.23 & 360 & 10.21 \\
\hline & 30 & 346.39 & 360 & 3.78 \\
\hline & 35 & 372.23 & 360 & -3.40 \\
\hline & 40 & 372.47 & 360 & -3.46 \\
\hline & 45 & 360.08 & 360 & -0.02 \\
\hline & 50 & 354.55 & 360 & 1.51 \\
\hline \multirow{6}{*}{ Yellow } & 25 & 397,85 & 450 & 11.59 \\
\hline & 30 & 439.02 & 450 & 2.44 \\
\hline & 35 & 470.82 & 450 & -4.63 \\
\hline & 40 & 470.57 & 450 & -4.57 \\
\hline & 45 & 472.17 & 450 & -4.93 \\
\hline & 50 & 471.68 & 450 & -4.82 \\
\hline \multirow{6}{*}{ Green } & 25 & 502.63 & 550 & 8.61 \\
\hline & 30 & 547.88 & 550 & 0.39 \\
\hline & 35 & 594.49 & 550 & -8.09 \\
\hline & 40 & 548.50 & 550 & 0.27 \\
\hline & 45 & 573.41 & 550 & -4.26 \\
\hline & 50 & 581.68 & 550 & -5.76 \\
\hline \multirow{6}{*}{ Red } & 25 & 630.61 & 670 & 5.88 \\
\hline & 30 & 688.47 & 670 & -2.76 \\
\hline & 35 & 691.89 & 670 & -3.27 \\
\hline & 40 & 724.71 & 670 & -8.17 \\
\hline & 45 & 686.44 & 670 & -2.45 \\
\hline & 50 & 683.11 & 670 & -1.96 \\
\hline
\end{tabular}

* Reported flow variation compared to the flow rate obtained.

The highest CVs were observed for the blue and yellow nozzles. As these present lower flow rates, they have a smaller opening; therefore, the process of manufacturing smaller holes may present greater variation. Increasing the working pressure of the sprinklers had a linear effect on the CV for all nozzles (Figure 2), whereby the CV increased with the working pressure. These results were also observed by Holanda Filho et al. (2001) and Martins et al. (2015). 
Table 4. Coefficient of variation (CV) for the blue, yellow, green, and red nozzles according to ABNT (2000), ASAE (1999), and Solomon (1979).

\begin{tabular}{|c|c|c|c|c|c|}
\hline \multirow{2}{*}{ Nozzle } & \multirow{2}{*}{$\begin{array}{c}\text { Pressure (m } \\
\left.\quad \mathrm{H}_{2} \mathrm{O}\right)\end{array}$} & \multirow{2}{*}{$\begin{array}{l}\mathrm{CV} \\
(\%)\end{array}$} & \multicolumn{3}{|c|}{ Classification of uniformity } \\
\hline & & & ABNT & ASAE & Solomon \\
\hline \multirow{6}{*}{ Blue } & 25 & 2.65 & Good & Excellent & Excellent \\
\hline & 30 & 3.54 & Good & Excellent & Average \\
\hline & 35 & 3.40 & Good & Excellent & Average \\
\hline & 40 & 3.80 & Good & Excellent & Average \\
\hline & 45 & 5.36 & Good & Average & Average \\
\hline & 50 & 5.48 & Good & Average & Average \\
\hline \multirow{6}{*}{ Yellow } & 25 & 1.97 & Good & Excellent & Excellent \\
\hline & 30 & 2.45 & Good & Excellent & Excellent \\
\hline & 35 & 2.50 & Good & Excellent & Excellent \\
\hline & 40 & 5,38 & Good & Average & Average \\
\hline & 45 & 7.89 & Good & Poor & Poor \\
\hline & 50 & 7.98 & Good & Poor & Poor \\
\hline \multirow{6}{*}{ Green } & 25 & 1.03 & Good & Excellent & Excellent \\
\hline & 30 & 1.29 & Good & Excellent & Excellent \\
\hline & 35 & 1.00 & Good & Excellent & Excellent \\
\hline & 40 & 1.06 & Good & Excellent & Excellent \\
\hline & 45 & 1.63 & Good & Excellent & Excellent \\
\hline & 50 & 1.85 & Good & Excellent & Excellent \\
\hline \multirow{6}{*}{ Red } & 25 & 0.97 & Good & Excellent & Excellent \\
\hline & 30 & 1.00 & Good & Excellent & Excellent \\
\hline & 35 & 1.50 & Good & Excellent & Excellent \\
\hline & 40 & 1.07 & Good & Excellent & Excellent \\
\hline & 45 & 1.34 & Good & Excellent & Excellent \\
\hline & 50 & 1.79 & Good & Excellent & Excellent \\
\hline
\end{tabular}

According to the manufacturer, the pressure (30 to $50 \mathrm{~m} \mathrm{H}_{2} \mathrm{O}$ ), and the average flow rate of these range in which the FR Super 10 sprinkler self- pressures was of $361.14 \mathrm{~L} \mathrm{~h}^{-1}$; the indicated flow compensates is 30 to $50 \mathrm{~m} \mathrm{H}_{2} \mathrm{O}$. The results of rate was $360 \mathrm{~L} \mathrm{~h}^{-1}$, which varied by $0.3 \%$. This was Tukey's test comparing the average flow at 25 to also observed with the yellow nozzle, the flow rates $50 \mathrm{~m} \mathrm{H}_{2} \mathrm{O}$ are shown in Table 5. The range of self- were not statistically different at pressures of 30 to compensation observed for the blue nozzle was $50 \mathrm{~m} \mathrm{H}_{2} \mathrm{O}$, and the variation between the observed consistent with that indicated by the manufacturer and indicated flow rate was $3.3 \%$. 
Figure 2. Relationship between the working pressures and CVFs for the blue, yellow, green, and red nozzles. $\left(* \mathrm{R}^{2}\right.$ significant at $5 \%$ probability).
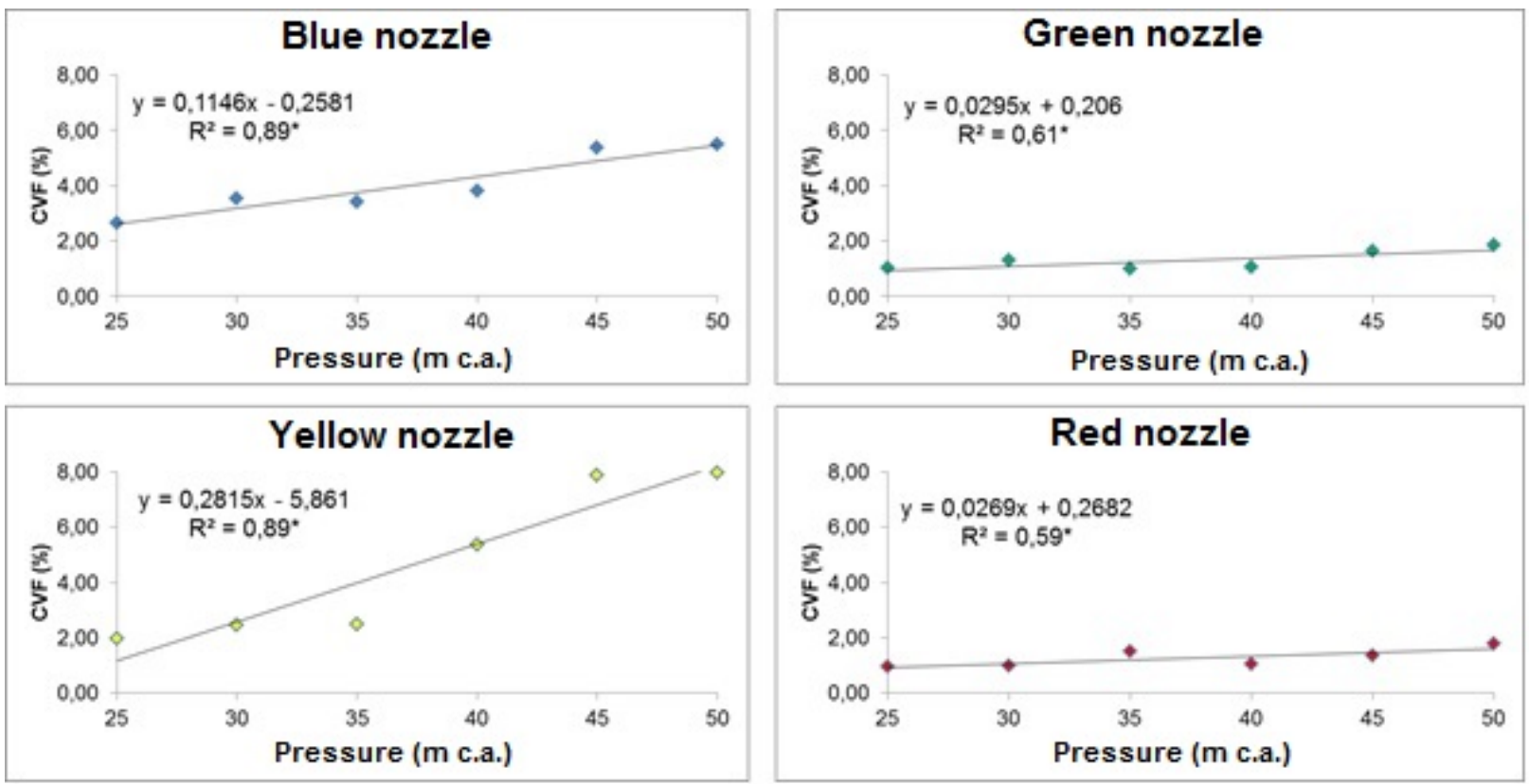

Table 5. Mean flow rates of blue, yellow, green, and red nozzles.

\begin{tabular}{|c|c|c|c|c|c|c|c|}
\hline Nozzle & Pressure $\left(\mathrm{m} \mathrm{H}_{2} \mathrm{O}\right)$ & $\begin{array}{c}\text { Flow rate } \\
\left(\mathrm{L} \mathrm{h}^{-1}\right)\end{array}$ & & Nozzle & Pressure $\left(\mathrm{m} \mathrm{H}_{2} \mathrm{O}\right)$ & $\begin{array}{c}\text { Flow rate } \\
\left(\mathrm{L} \mathrm{h}^{-1}\right)\end{array}$ & \\
\hline \multirow{6}{*}{ Blue } & 25 & 323.23 & $\mathrm{~B}$ & \multirow{6}{*}{ Verde } & 25 & 502.63 & $\mathrm{~d}$ \\
\hline & 30 & 346.39 & $\mathrm{Ab}$ & & 30 & 547.88 & $\mathrm{c}$ \\
\hline & 35 & 372.23 & A & & 35 & 594.49 & $\mathrm{a}$ \\
\hline & 40 & 372.47 & A & & 40 & 548.5 & $\mathrm{c}$ \\
\hline & 45 & 360.08 & A & & 45 & 573.41 & $\mathrm{~b}$ \\
\hline & 50 & 354.55 & $a b$ & & 50 & 581.68 & $a b$ \\
\hline Dms* & & 36.35 & & & & 19.06 & \\
\hline CV (\%) & & 4.56 & & & & 1.52 & \\
\hline Average* & & 361.14 & & & & 569.19 & \\
\hline \multirow{6}{*}{ Yellow } & 25 & 397.85 & $\mathrm{~b}$ & \multirow{6}{*}{ Red } & 25 & 630.61 & $\mathrm{c}$ \\
\hline & 30 & 439.02 & $a b$ & & 30 & 688.47 & $\mathrm{~b}$ \\
\hline & 35 & 470.82 & $\mathrm{a}$ & & 35 & 691.89 & $\mathrm{~b}$ \\
\hline & 40 & 470.57 & $\mathrm{a}$ & & 40 & 724.71 & $\mathrm{a}$ \\
\hline & 45 & 472.17 & A & & 45 & 686.44 & b \\
\hline & 50 & 471.68 & A & & 50 & 683.11 & $\mathrm{~b}$ \\
\hline Dms & & 70.25 & & & & 25.21 & \\
\hline CV $(\%)$ & & 6.90 & & & & 1.58 & \\
\hline Average** & & 464.85 & & & & 694.92 & \\
\hline
\end{tabular}

* Dms, significant minimum deviation;

**Average flow rate obtained at 30 to $50 \mathrm{~m} \mathrm{H}_{2} \mathrm{O}$. Means followed by the same letter, in the same column, do not differ by Tukey's test at $1 \%$ probability. 
The green nozzle was not perfectly selfcompensating and did not have a well-defined compensation range, but the average flow rates at pressures where the sprinkler compensated (569.19 $\mathrm{L} \mathrm{h}^{-1}$ ) varied by $3.5 \%$, which was very close to that presented by the yellow nozzle (3.3\%) as indicated by the manufacturer ( 30 to $50 \mathrm{~m} \mathrm{H}_{2} \mathrm{O}$ ). The low variation in relation to the catalogue $(3.5 \%)$ is not relevant, allowing the use of this catalogue flow in irrigation projects.

The Super 10 sprinkler model is available with and without self-compensation. Martins et al. (2015) evaluated the Super 10 sprinkler without pressure compensator and found that flow increased with pressure.

The flow rates obtained for the red nozzle at pressures of $30,35,45$, and $50 \mathrm{~m} \mathrm{H}_{2} \mathrm{O}$ were not statistically different, but the flow obtained at $40 \mathrm{~m}$ $\mathrm{H}_{2} \mathrm{O}$ was higher than that at the other pressures. The variation between the average flow rate at 30 to 50 $\mathrm{m} \mathrm{H}_{2} \mathrm{O}$, and the flow rate indicated in the catalogue for this range, was $3.7 \%$, which would not impair an irrigation project.
ABNT (2000) imposes a 5\% limit on the amount of variation with a nominal flow greater than $250 \mathrm{~L}$ $\mathrm{h}^{-1}$. Therefore, the results observed with all nozzles are below this limit, corroborating the variation reported by Martins et al. (2015), which was below $4 \%$ for the Super 10 sprinkler without compensation.

Graphs (Figure 3 and 4) and equations (Table 6) were generated to show the flow data obtained at the pressures tested in order to assess the representative equations of flow $\times$ pressure as proposed by Keller and Karmeli (1974). As the sprinkler is selfcompensating, the exponent " $\times$ " has values close to 0 for the four nozzles; therefore, the flow is stable with pressure variation. The regression models best adjusted (higher $\mathrm{R}^{2}$ ) for all nozzles were obtained at a pressure of $25 \mathrm{~m} \mathrm{H}_{2} \mathrm{O}$, and the coefficient of the equation was considered significant for the yellow nozzle only when the pressure differed from $25 \mathrm{~m}$ $\mathrm{H}_{2} \mathrm{O}$. According to the manufacture's catalogue, this pressure is not within the sprinkler compensation range ( 30 to $50 \mathrm{~m} \mathrm{H}_{2} \mathrm{O}$ ).

Figure 3. Characteristic flow $\times$ pressure curves for the Super 10 self-compensating sprinkler with blue, yellow, green, and red nozzles, at pressures of 25 to $50 \mathrm{~m} \mathrm{H}_{2} \mathrm{O}$.

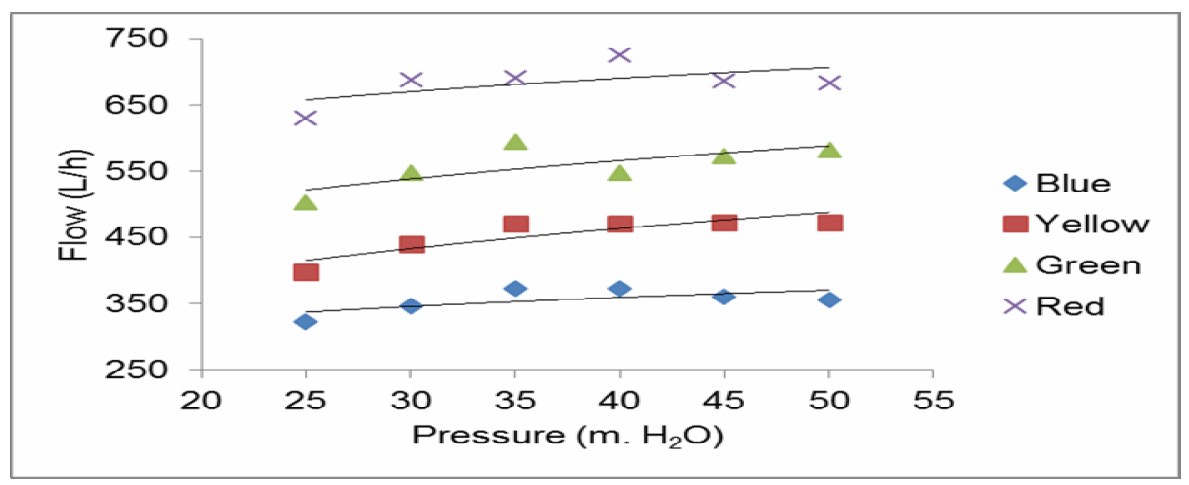


Figure 4. Characteristic flow $\times$ pressure curves for the Super 10 self-compensating sprinkler with blue, yellow, green, and red nozzles, at pressures of 30 to $50 \mathrm{~m} \mathrm{H}_{2} \mathrm{O}$.

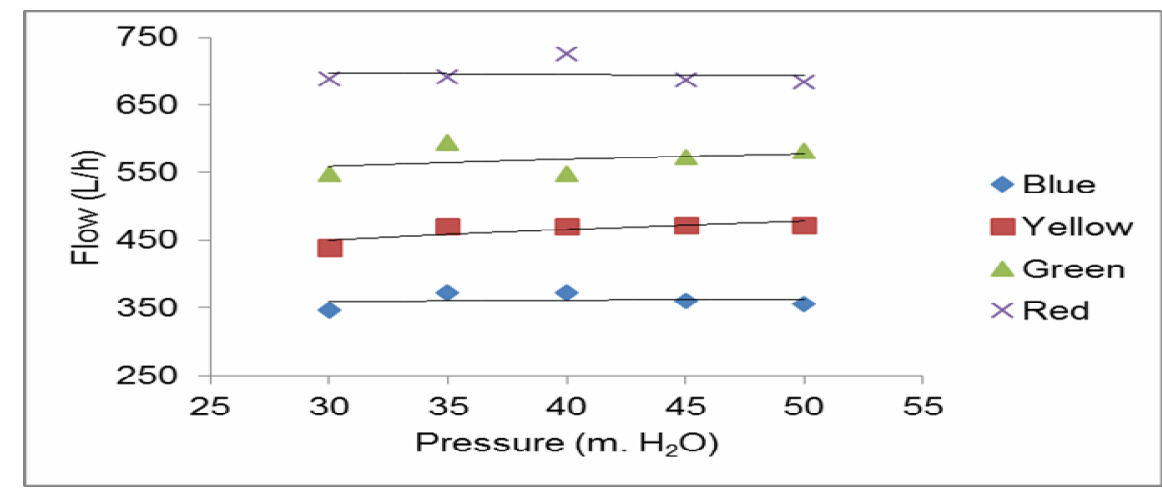

The potential model does not present a good fit, as the $\mathrm{R}^{2}$ values were low (Table 6). Lopez et al. (1997) studied self-compensating drippers and observed that an exponential model is poor when applied to self-compensating emitters, thus explaining the best fit of the quadratic model. According to the coefficient of determination $\left(\mathrm{R}^{2}\right)$, the quadratic model (Figures 5 and 6, and Table 7) displayed a better fit compared to the exponential model. With the exception of the green nozzle, when a pressure of $25 \mathrm{~m} \mathrm{H}_{2} \mathrm{O}$ was used, which was not in the compensation range ( 30 to $50 \mathrm{~m} \mathrm{H}_{2} \mathrm{O}$ ), all equations presented an $\mathrm{R}^{2}$ greater than $80 \%$. Only the sprinkler with the green nozzle was not perfectly self-compensating (Table 5). In the power regression model, without the use of lower pressure $\left(25 \mathrm{~m} \mathrm{H}_{2} \mathrm{O}\right)$ to elaborate the regression model, the fit of the equations, given by $\mathrm{R}^{2}$, was lower (Table 6).

Table 6. Flow $\times$ pressure and coefficients of determination $\left(\mathrm{r}^{2}\right)$ obtained for the four nozzles.

\begin{tabular}{ccc}
\hline Nozzle & Equation q $=\mathrm{K} \mathrm{H}^{\mathrm{x}}$ & $\mathrm{R}^{2}$ \\
\hline Blue (pressure of 25 to $50 \mathrm{~m} \mathrm{H}_{2} \mathrm{O}$ ) & $217.86 \mathrm{H}^{0.1353}$ & 0.43 \\
Blue (pressure of 30 to $50 \mathrm{~m} \mathrm{H}_{2} \mathrm{O}$ ) & $333.82 \mathrm{H}^{0.0213}$ & 0.76 \\
\hline Yellow (pressure of 25 to $50 \mathrm{~m} \mathrm{H}_{2} \mathrm{O}$ ) & $194.69 \mathrm{H}^{0.2346}$ & 0.60 \\
\hline Yellow (pressure of 30 to $50 \mathrm{~m} \mathrm{H}_{2} \mathrm{O}$ ) & $297.34 \mathrm{H}^{0.1215}$ & 0.55 \\
\hline Green (pressure of 25 to $50 \mathrm{~m} \mathrm{H}_{2} \mathrm{O}$ ) & $299.78 \mathrm{H}^{0.1724}$ & $\mathrm{~ns}$ \\
Green (pressure of 30 to $50 \mathrm{~m} \mathrm{H}_{2} \mathrm{O}$ ) & $445.56 \mathrm{H}^{0.0665}$ & 0.35 \\
\hline Red (pressure of 25 to $50 \mathrm{~m} \mathrm{H}_{2} \mathrm{O}$ ) & $471.19 \mathrm{H}^{0.1035}$ & $\mathrm{~ns}$ \\
Red (pressure of 30 to $50 \mathrm{~m} \mathrm{H}_{2} \mathrm{O}$ ) & $727.20 \mathrm{H}^{-0.0120}$ & \\
\hline
\end{tabular}

ns, not significant with the $\mathrm{F}$ test $(\mathrm{P}>0.05)$.

According to the analysis of variance $(\mathrm{P}<0.05)$, the effect of pressure on CUC and CUD, as well as the interaction between height and pressure, was not significant. Height was significant and the means were compared by Tukey's test (Table 7). Table 7 shows that CUC and CUD were higher for all nozzles at the maximum height $(1.2 \mathrm{~m})$ compared with the values at the minimum height $(0.6 \mathrm{~m})$, indicating that increased height improved the distribution of uniformity for the sprinklers. 
Figure 5. Second-degree adjustment model of the relationship between flow $\times$ pressure for the Super 10 selfcompensating sprinkler, with blue, yellow, green, and red nozzles, at pressures of 25 to $50 \mathrm{~m} \mathrm{H}_{2} \mathrm{O}$.

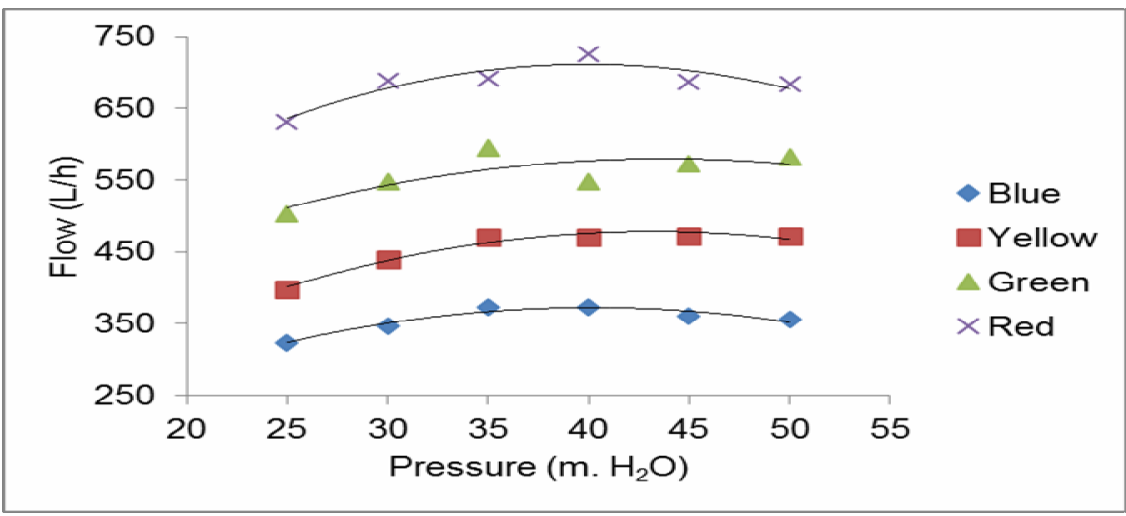

Figure 6. Second-degree adjustment model of the relationship between flow $\times$ pressure for the Super 10 selfcompensating sprinkler, with blue, yellow, green, and red nozzles, at pressures from 25 to $50 \mathrm{~m} \mathrm{H}_{2} \mathrm{O}$.

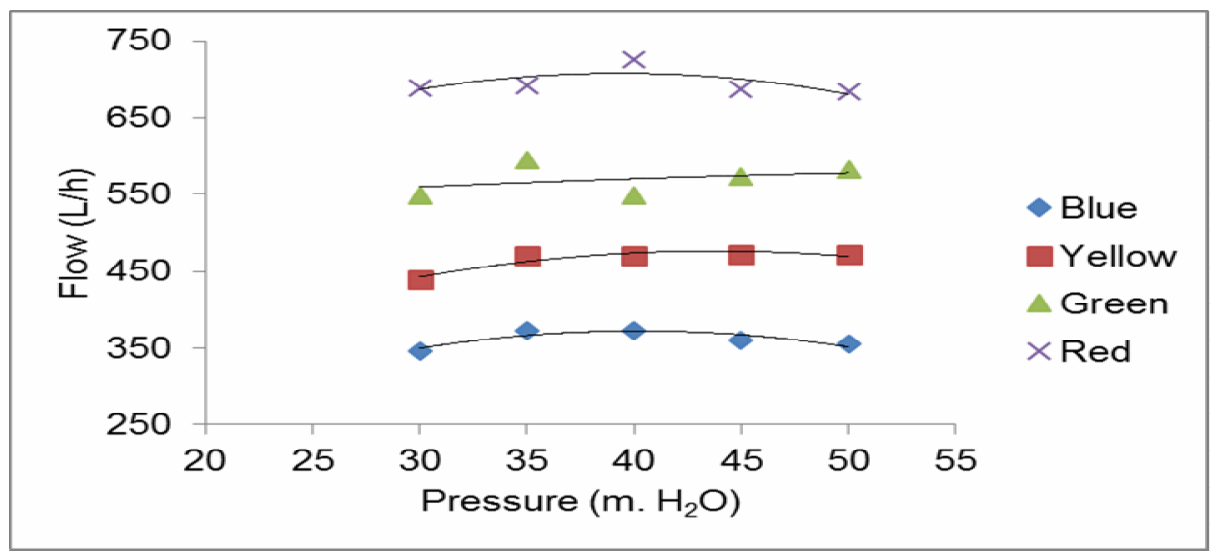

Table 7. Second-degree equations $\left(\mathrm{q}=\mathrm{aH}^{2}+\mathrm{bH}+\mathrm{c}\right)$ between flow $\times$ pressure and coefficient of determination $\left(\mathrm{R}^{2}\right)$ obtained for the four nozzles.

\begin{tabular}{ccc}
\hline Nozzle & Equation & $\mathrm{R}^{2}$ \\
\hline Blue (pressure of 25 to $50 \mathrm{~m} \mathrm{H}_{2} \mathrm{O}$ ) & $-0.2117 \mathrm{H}^{2}+17.005 \mathrm{H}+30.204$ & 0.94 \\
Blue (pressure of 30 to $50 \mathrm{~m} \mathrm{H}_{2} \mathrm{O}$ ) & $-0.2153 \mathrm{H}^{2}+17.308 \mathrm{H}+24.071$ & 0.80 \\
\hline Yellow (pressure of 25 to $50 \mathrm{~m} \mathrm{H}_{2} \mathrm{O}$ ) & $-0.2351 \mathrm{H}^{2}+20.305 \mathrm{H}+39.915$ & 0.97 \\
Yellow (pressure of 30 to $50 \mathrm{~m} \mathrm{H}_{2} \mathrm{O}$ ) & $-0.1792 \mathrm{H}^{2}+15.673 \mathrm{H}+133.68$ & 0.87 \\
\hline Green (pressure of 25 to $\left.50 \mathrm{~m} \mathrm{H}_{2} \mathrm{O}\right)$ & $-0.1941 \mathrm{H}^{2}+16.990 \mathrm{H}+208.07$ & 0.64 \\
Green (pressure of 30 to $50 \mathrm{~m} \mathrm{H}_{2} \mathrm{O}$ ) & $-0.0166 \mathrm{H}^{2}+2.2569 \mathrm{H}+506.27$ & ns \\
\hline Red (pressure of 25 to $\left.50 \mathrm{~m} \mathrm{H}_{2} \mathrm{O}\right)$ & $-0.3377 \mathrm{H}^{2}+26.977 \mathrm{H}+172.01$ & 0.84 \\
Red (pressure of 30 to $50 \mathrm{~m} \mathrm{H}_{2} \mathrm{O}$ ) & $-0.2417 \mathrm{H}^{2}+19.009 \mathrm{H}+333.33$ & 0.47 \\
\hline
\end{tabular}

ns, not significant by the $\mathrm{F}$ test $(\mathrm{P}>0.05)$. 
As shown in Table 8, when considering the combined CUC and CUD for all nozzles (MANTOVANI, 2001), excellent values were only found at a height of $1.2 \mathrm{~m}$. Due to its lower flow $\left(360 \mathrm{~L} \mathrm{~h}^{-1}\right)$, the manufacturer recommends installing the blue nozzle at smaller spacings, which was also observed in the present study (Table 4). With less pressure, and with larger row spacings, excellent CUC and CUD values were obtained. The manufacturer recommends the use of this nozzle only at $9 \times 9,9 \times 10$, and $10 \times 10$ row spacings. Guirra et al. (2013) and Martins et al. (2012) also found that CUC and CUD decreased with larger spacings. However, one should also note that the use of smaller spacings increases the cost of the system owing to the piping and labor needed for the transportation of delivery lines (PEREIRA, 2003).

Excellent CUC and CUD values were found for the yellow nozzle at pressures of 35 to $50 \mathrm{~m} \mathrm{H}_{2} \mathrm{O}$, but at $40 \mathrm{~m} \mathrm{H}_{2} \mathrm{O}$, excellent values were only found at the smallest spacing $(9 \times 9 \mathrm{~m})$. Even with the pressure compensator, the CUC and CUD for the two lowest pressures ( 25 and $30 \mathrm{~m} \mathrm{H}_{2} \mathrm{O}$ ) were not excellent. At a height of $0.6 \mathrm{~m}$, and for the largest spacings $(9 \times$ $12,10 \times 12,12 \times 12 \mathrm{~m}$ ) at all pressures, only good CUC and CUD values were found (Table 8).

Table 8. Mean CUC and CUD values for the two installation heights ( 0.6 and $1.2 \mathrm{~m})$.

\begin{tabular}{|c|c|c|c|c|}
\hline \multirow{3}{*}{ Nozzle } & \multicolumn{2}{|c|}{ CUC (\%) } & \multicolumn{2}{|c|}{ CUD (\%) } \\
\hline & \multicolumn{4}{|c|}{ Height $(\mathrm{m})$} \\
\hline & 0.6 & 1.2 & 0.6 & 1.2 \\
\hline Blue & $78.40 \mathrm{~b}$ & $88.27 \mathrm{a}$ & $75.96 \mathrm{~b}$ & $82.55 \mathrm{a}$ \\
\hline Yellow & $86.14 \mathrm{~b}$ & $88.60 \mathrm{a}$ & $82.66 \mathrm{~b}$ & $84.86 \mathrm{a}$ \\
\hline Green & $84.81 \mathrm{~b}$ & $89.55 \mathrm{a}$ & $80.92 \mathrm{~b}$ & $84.86 \mathrm{a}$ \\
\hline Red & $81.76 \mathrm{~b}$ & $87.36 \mathrm{a}$ & $75.10 \mathrm{~b}$ & $81.30 \mathrm{a}$ \\
\hline Dms & \multicolumn{2}{|c|}{1.47} & & \\
\hline
\end{tabular}

Means followed by the same letter in the row for CUC and CUD, do not differ by Tukey's test at $1 \%$ probability.

Green and red nozzles have larger flow rates, and excellent CUC and CUD values were found only at a height of $1.2 \mathrm{~m}$ (Table 9). For the smallest spacing $(9 \times 9 \mathrm{~m})$, no excellent values were found for CUC and CUD.

Unlike the other nozzles, the green and red nozzles are indicated for use at larger spacings, and this has been verified through the CUC and CUD values, which were considered good for almost all heights and pressures (Table 9).

Uniformity improved as the installation height of the sprinkler increased; however, these values were obtained in the absence of wind interference, and under field conditions, these values can vary and subsequently decrease uniformity.
Oliveira et al. (2009) tested the effect of wind on the wetness radius of the Plona RL-250 irrigation gun and found that the water jet displayed a linear relationship with wind. When the wind is in the same direction as the water jet, the radius of wetness increases and when the wind direction is opposite to the water jet, the radius of wetness decreases.

For irrigation in the presence of wind, it is recommended that the spacing is decreased (BERNARDO et al., 2006), because with lower row spacing there will be greater overlap of water depths, thereby reducing the effect of the wind, and maintaining the appropriate uniformity. 
Table 9. Mean CUC (\%) and CUD (\%) values according to pressure, height, and spacing for the blue, yellow, green, and red nozzles.

\begin{tabular}{|c|c|c|c|c|c|c|c|c|c|c|c|c|c|c|}
\hline \multirow{3}{*}{ Nozzle } & \multirow{3}{*}{$\begin{array}{l}\text { Pressure } \\
\left(\mathrm{m} \mathrm{H}_{2} \mathrm{O}\right)\end{array}$} & \multirow{3}{*}{$\begin{array}{l}\text { Height } \\
\text { (m) }\end{array}$} & \multicolumn{12}{|c|}{ Row spacings $(\mathrm{m} \times \mathrm{m})$} \\
\hline & & & \multicolumn{2}{|c|}{$9 \times 9$} & \multicolumn{2}{|c|}{$9 \times 10$} & \multicolumn{2}{|c|}{$9 \times 12$} & \multicolumn{2}{|c|}{$10 \times 10$} & \multicolumn{2}{|c|}{$10 \times 12$} & \multicolumn{2}{|c|}{$12 \times 12$} \\
\hline & & & CUC & CUD & CUC & CUD & CUC & CUD & CUC & CUD & CUC & CUD & CUC & CUD \\
\hline \multirow{12}{*}{ Blue } & \multirow{2}{*}{25} & 0.6 & 77.9 & 77.8 & 76.6 & 75.3 & 74.0 & 71.8 & 75.4 & 74.3 & 73.2 & 69.8 & 71.3 & 65.5 \\
\hline & & 1.2 & 89.0 & 84.7 & 87.9 & 83.4 & 84.4 & 77.9 & 87.1 & 83.1 & 82.8 & 75.7 & 78.4 & 67.0 \\
\hline & \multirow{2}{*}{30} & 0.6 & 82.4 & 82.5 & 81.5 & 80.5 & 78.8 & 75.8 & 80.9 & 78.9 & 78.2 & 73.8 & 75.9 & 69.5 \\
\hline & & 1.2 & 92.0 & 88.0 & 91.7 & 87.4 & 87.5 & 80.8 & 91.1 & 86.3 & 86.1 & 78.2 & 81.4 & 71.4 \\
\hline & \multirow{2}{*}{35} & 0.6 & 86.0 & 85.6 & 84.5 & 83.9 & 81.0 & 78.0 & 84.1 & 82.4 & 80.4 & 76.5 & 77.9 & 72.3 \\
\hline & & 1.2 & 93.7 & 90.0 & 92.8 & 89.3 & 87.6 & 81.2 & 91.4 & 87.9 & 86.5 & 79.3 & 82.4 & 73.5 \\
\hline & \multirow{2}{*}{40} & 0.6 & 84.3 & 84.5 & 83.3 & 82.5 & 78.8 & 74.8 & 82.2 & 81.4 & 78.1 & 73.6 & 74.6 & 67.7 \\
\hline & & 1.2 & 93.5 & 90.5 & 92.8 & 89.4 & 88.4 & 82.4 & 92.1 & 88.2 & 87.3 & 80.5 & 83.4 & 74.6 \\
\hline & \multirow{2}{*}{45} & 0.6 & 80.6 & 80.5 & 79.2 & 78.8 & 74.3 & 71.8 & 77.6 & 77.4 & 73.2 & 70.0 & 69.7 & 65.4 \\
\hline & & 1.2 & 93.3 & 90.3 & 92.6 & 88.9 & 86.9 & 80.9 & 91.7 & 87.8 & 85.7 & 78.4 & 81.7 & 72.0 \\
\hline & 50 & 0.6 & 82.3 & 81.8 & 80.7 & 80.5 & 76.5 & 72.7 & 79.5 & 78.9 & 75.8 & 72.0 & 72.2 & 66.4 \\
\hline & 50 & 1.2 & 93.0 & 90.2 & 92.5 & 89.0 & 88.1 & 82.3 & 91.9 & 87.8 & 86.8 & 80.2 & 82.9 & 73.6 \\
\hline & & 0.6 & 84.7 & 82.0 & 84.9 & 81.2 & 82.8 & 77.6 & 83.0 & 78.9 & 82.7 & 77.2 & 82.9 & 77.3 \\
\hline & 25 & 1.2 & 88.0 & 85.5 & 89.1 & 85.7 & 86.6 & 82.5 & 87.9 & 83.6 & 86.5 & 81.2 & 85.9 & 80.6 \\
\hline & & 0.6 & 85.9 & 82.5 & 86.7 & 82.9 & 85.6 & 81.4 & 85.9 & 82.6 & 85.1 & 80.8 & 84.9 & 79.8 \\
\hline & 30 & 1.2 & 87.9 & 84.6 & 89.7 & 86.4 & 87.8 & 82.8 & 88.9 & 85.2 & 87.2 & 81.9 & 86.2 & 80.5 \\
\hline & & 0.6 & 87.2 & 84.1 & 87.8 & 84.8 & 86.3 & 83.0 & 87.1 & 84.2 & 85.9 & 81.9 & 85.2 & 80.0 \\
\hline & 35 & 1.2 & 89.4 & 86.1 & 91.1 & 87.9 & 89.3 & 85.1 & 90.6 & 87.5 & 88.8 & 83.8 & 87.5 & 82.1 \\
\hline Yellow & & 0.6 & 87.1 & 85.7 & 87.7 & 85.8 & 86.6 & 84.1 & 87.3 & 84.8 & 86.5 & 83.1 & 86.0 & 81.6 \\
\hline & 40 & 1.2 & 90.1 & 86.7 & 91.9 & 88.5 & 90.2 & 86.0 & 91.6 & 88.8 & 89.7 & 84.6 & 88.2 & 82.2 \\
\hline & 15 & 0.6 & 87.0 & 84.9 & 87.7 & 85.2 & 86.5 & 83.3 & 86.9 & 84.2 & 86.2 & 82.1 & 85.8 & 81.4 \\
\hline & 45 & 1.2 & 89.7 & 85.7 & 91.7 & 88.2 & 90.1 & 85.4 & 91.6 & 88.3 & 89.3 & 83.8 & 87.7 & 81.7 \\
\hline & 50 & 0.6 & 87.8 & 85.9 & 88.6 & 86.1 & 87.4 & 84.2 & 88.0 & 85.4 & 87.0 & 83.4 & 87.1 & 82.7 \\
\hline & 50 & 1.2 & 89.0 & 84.5 & 91.5 & 88.4 & 90.4 & 85.3 & 91.9 & 89.0 & 69.1 & 84.0 & 87.9 & 81.3 \\
\hline & 25 & 0.6 & 82.9 & 78.3 & 85.1 & 82.3 & 84.7 & 79.9 & 85.4 & 83.5 & 83.6 & 79.0 & 82.8 & 75.8 \\
\hline & 25 & 1.2 & 86.0 & 80.5 & 88.1 & 83.2 & 88.5 & 82.4 & 88.9 & 84.3 & 87.3 & 82.5 & 86.6 & 79.6 \\
\hline & 30 & 0.6 & 83.4 & 79.1 & 85.4 & 82.5 & 85.2 & 80.5 & 85.8 & 83.5 & 84.3 & 80.1 & 83.4 & 76.5 \\
\hline & 30 & 1.2 & 88.2 & 83.5 & 90.2 & 86.3 & 89.9 & 84.9 & 90.3 & 86.7 & 89.2 & 85.1 & 88.6 & 82.9 \\
\hline & 35 & 0.6 & 84.5 & 80.6 & 86.0 & 83.3 & 85.4 & 81.9 & 86.1 & 84.0 & 84.7 & 81.5 & 84.0 & 78.1 \\
\hline Green & 35 & 1.2 & 88.8 & 84.9 & 90.4 & 86.8 & 90.4 & 85.6 & 90.4 & 86.0 & 89.5 & 85.7 & 88.9 & 84.0 \\
\hline & 40 & 0.6 & 85.7 & 82.2 & 87.1 & 84.7 & 86.2 & 84.1 & 86.9 & 85.5 & 85.7 & 83.0 & 84.6 & 79.0 \\
\hline & 40 & 1.2 & 89.7 & 85.2 & 91.0 & 87.4 & 91.1 & 86.2 & 91.1 & 86.8 & 89.9 & 86.4 & 89.5 & 84.9 \\
\hline & 45 & 0.6 & 83.2 & 78.2 & 85.1 & 80.6 & 84.9 & 80.7 & 85.5 & 82.4 & 84.0 & 81.0 & 83.0 & 77.0 \\
\hline & 43 & 1.2 & 87.9 & 82.0 & 89.3 & 84.1 & 90.6 & 84.5 & 90.5 & 86.3 & 89.9 & 85.5 & 88.9 & 82.3 \\
\hline & 50 & 0.6 & 83.7 & 78.8 & 85.6 & 81.5 & 85.4 & 81.5 & 86.0 & 83.9 & 84.6 & 81.5 & 83.7 & 77.3 \\
\hline & & 1.2 & 89.8 & 85.0 & 90.8 & 87.1 & 91.5 & 86.6 & 91.8 & 88.8 & 90.6 & 86.8 & 90.0 & 84.2 \\
\hline & 25 & 0.6 & 79.9 & 73.1 & 82.5 & 77.0 & 83.0 & 77.2 & 83.4 & 80.3 & 82.1 & 77.1 & 80.5 & 71.4 \\
\hline & & 1.2 & 86.2 & 81.6 & 88.6 & 85.4 & 87.8 & 78.6 & 88.9 & 85.2 & 86.6 & 80.6 & 85.5 & 78.8 \\
\hline & 30 & 0.6 & 78.9 & 70.8 & 82.0 & 74.5 & 82.7 & 76.4 & 83.2 & 79.2 & 81.7 & 76.6 & 80.2 & 69.5 \\
\hline & 30 & 1.2 & 87.3 & 82.5 & 90.3 & 86.3 & 89.3 & 84.3 & 90.6 & 87.9 & 88.4 & 83.0 & 86.4 & 79.0 \\
\hline & & 0.6 & 78.9 & 70.6 & 81.6 & 74.0 & 82.4 & 76.2 & 82.9 & 78.5 & 81.2 & 76.5 & 79.7 & 69.7 \\
\hline & 35 & 1.2 & 84.9 & 77.3 & 88.0 & 81.0 & 88.7 & 81.9 & 89.9 & 85.1 & 88.3 & 82.4 & 85.9 & 76.7 \\
\hline Red & 40 & 0.6 & 79.2 & 71.0 & 82.0 & 74.5 & 82.7 & 76.3 & 83.2 & 78.5 & 81.5 & 76.8 & 79.9 & 70.0 \\
\hline & 40 & 1.2 & 84.1 & 76.6 & 86.9 & 80.0 & 88.1 & 80.6 & 88.7 & 83.9 & 87.4 & 81.3 & 85.4 & 76.3 \\
\hline & 45 & 0.6 & 79.8 & 71.8 & 82.4 & 75.3 & 83.2 & 76.7 & 83.9 & 79.2 & 82.1 & 77.2 & 80.8 & 71.0 \\
\hline & 45 & 1.2 & 85.0 & 78.7 & 87.8 & 82.1 & 88.0 & 81.6 & 88.5 & 84.6 & 87.1 & 81.4 & 85.3 & 77.5 \\
\hline & 50 & 0.6 & 80.6 & 72.9 & 82.8 & 76.1 & 83.9 & 77.6 & 84.3 & 79.9 & 82.9 & 78.4 & 81.6 & 72.4 \\
\hline & & 1.2 & 84.9 & 78.5 & 87.5 & 81.6 & 87.9 & 81.5 & 88.2 & 84.0 & 87.3 & 81.6 & 85.7 & 77.9 \\
\hline
\end{tabular}

Legend: Data Set (CUC and CUD) Blue represents CUC $>90$ and CUD $>84$, rated as excellent; Grey represents CUC between 80 and 90 and CUD between 68 and 84, classified as good; and no shading represents CUC $<80$ and CUD $<68$, classified as average (MANTOVANI, 2001). 
As shown in Figure 7, the radial profiles for all pressures revealed high levels of irrigation $0.5 \mathrm{~m}$ from the base of the sprinkler. Although precipitation was not collected at $0 \mathrm{~m}$, the distribution profiles indicate a trend of increased precipitation at this distance. This hampers the distribution uniformity and can cause excess irrigation near the sprinkler, which was also observed by Martins et al. (2015). With increasing sprinkler height, the distribution improved over the working range of the sprinkler and a smaller accumulation of water was observed in the first water catch can $(0.5 \mathrm{~m}$ from the base of the sprinkler).

Another important fact to consider is that the operating range of the sprinklers did not change with the change in pressure (Table 10). This is because the sprinkler possesses a pressure compensator to regulate the flow, which maintains the flow at different pressures. With the increase in the sprinkler's installation height, no increase in the wetness radius was observed; however, distribution uniformity improved, together with a decrease in the amount of water applied near the sprinkler.

Figure 7. Water distribution profiles of the four nozzles at six pressures and two installation heights $(0.6$ and $1.2 \mathrm{~m})$.
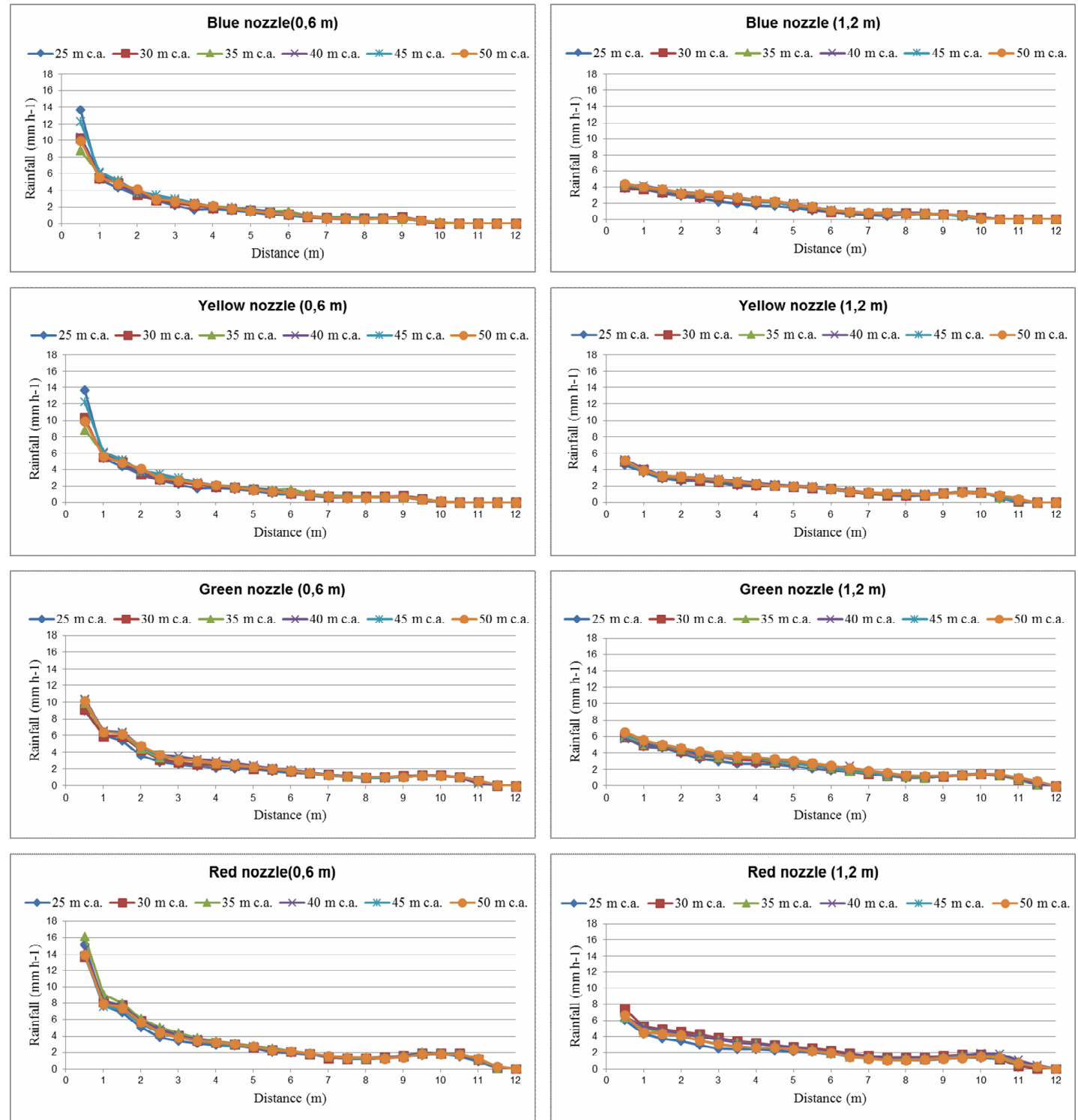
Table 10. Working range of the four nozzles in relation to the installation height and working pressures.

\begin{tabular}{cccccccc}
\hline \multirow{2}{*}{ Nozzle } & \multirow{2}{*}{ Height $(\mathrm{m})$} & \multicolumn{7}{c}{ Pressure $\left(\mathrm{m} \mathrm{H}_{2} \mathrm{O}\right)$} \\
\cline { 3 - 7 } & & 25 & 30 & 35 & 40 & 45 & 50 \\
\hline \multirow{2}{*}{ Blue } & 0.6 & 10 & 10 & 10 & 10 & 10 & 10 \\
& 1.2 & 10 & 10 & 10 & 10 & 10 & 10 \\
\hline \multirow{2}{*}{ Yellow } & 0.6 & 10 & 10 & 10 & 10 & 10 & 10 \\
& 1.2 & 10 & 10 & 10 & 10 & 10 & 10 \\
\hline \multirow{2}{*}{ Green } & 0.6 & 11.5 & 11.5 & 11.5 & 11.5 & 11.5 & 11.5 \\
& 1.2 & 11.5 & 11.5 & 11.5 & 11.5 & 11.5 & 11.5 \\
\hline \multirow{2}{*}{ Red } & 0.6 & 11.5 & 11.5 & 11.5 & 11.5 & 11.5 & 11.5 \\
& 1.2 & 11.5 & 11.5 & 11.5 & 11.5 & 11.5 & 11.5 \\
\hline
\end{tabular}

\section{Conclusions}

Smaller nozzles (blue and yellow) present higher CVs compared to larger nozzles (green and red).

The blue, yellow, and red nozzles presented selfcompensating behavior, and the green nozzle was not perfectly self-compensating.

Increasing the sprinkler installation height $(0.6$ to $1.2 \mathrm{~m}$ ) improves distribution uniformity and decreases the amount of water applied close to the sprinkler for all nozzles.

The pressure compensator allows an equal operating range of the sprinkler for all pressures between 25 and $50 \mathrm{~m} \mathrm{H}_{2} \mathrm{O}$.

Increasing the row spacings resulted in a decrease in the CUC and CUD values, especially for smaller nozzles (blue $<$ yellow $<$ green $<$ red).

Increased flow with larger nozzles (blue $<$ yellow $<$ green $<$ red) enables the use of greater spacing between sprinklers, thereby resulting in the best CUC and CUD values.

\section{Acknowledgements}

We would like to thank NaanDan Jain Irrigation Ltd. and Indústria de Rações Patense Ltd. for their financial support.

\section{References}

ALLEN, R.G. Catch-3D sprinkler pattern analysis software: user's manual. Logan: Utah State University, Department of Biological and Irrigation Engineering, 1992. $14 \mathrm{p}$

ALVAREZ, J. F. O.; BENITO, J. M. T. M.; VALERO, J. A. J.; PÉREZ, P. C. Uniformity distribution and its economic effect on irrigation management in semiarid zones. Journal of Irrigation and Drainage Engineering, Delaware, v. 130, n. 4, p. 257-268, 2004.

AMERICAN SOCIETY OF AGRICULTURAL ENGINEERS - ASAE. Standards 1999 Standards engineering practices data: EP405.1. Design and installation of microirrigation systems. St. Joseph. Mich: American Society of Agricultural Engineers, dec. 1999. p. 879-883.

ASSOCIAÇÃO BRASILEIRA DE NORMAS TÉCNICAS - ABNT. Equipamentos de irrigação agrícola: Aspersores rotativos. Parte 1: Requisitos para projetos e operação. Parte 2: uniformidade de distribuição e métodos de ensaio. Rio de Janeiro: ABNT, 2000. 22 p.

BERNARDO, S.; SOARES, A. A.; MANTOVANI, E. C. Manual de irrigação. 8. ed. Viçosa, MG: UFV: Imprensa Universitária, 2006. 625 p.

CHRISTIANSEN, J. E. Irrigation by sprinkler. Berkeley: California Agricultural Station, 1942. 212 p. (Bulletin, 670).

CLEMMENS, A. J.; MOLDEN, D. J. Water uses and productivity of irrigation systems. Irrigation Science, Heidelberg, v. 25, n. 3, p. 247-261, 2007.

CRIDDLE, W. D.; DAVIS, S.; PAIR, C. H.; SHOCKELEY, D. G. Methods for evaluating irrigation systems. Washington: SCS-USDA, 1956. 24 p. (Agricultural Handbook, 82). 
GOMIDE, D. J. L. Determinação e análise da uniformidade de distribuição de águano sistema de irrigação por aspersão. 1978. Dissertação (Mestrado em Engenharia Agrícola, Irrigação e Drenagem) Universidade Federal de Lavras, Lavras.

GUIRRA, A. P. P. M.; ZANINI, J. R.; SILVA, E. R. Desempenho do aspersor NaanDanJain 435 em função da posição do defletor. Científica, Jaboticabal, v. 41, n. 1, p. 21-32, 2013.

HOLANDA FILHO, R. S. F.; PORTO FILHO, F. Q.; MIRANDA, N. O.; MEDEIROS, J. F. Caracterização hidráulica do microaspersor Rondo, da Plastro. Revista Brasileira de Engenharia Agrícola e Ambiental, Campina Grande, v. 5, n. 1, p. 656-661, 2001.

KELLER, J.; KARMELI, D. Trickle irrigation design parameters. Transactions of the ASAE, St. Joseph, v. 17, n. 2, p. 678-684, 1974.

LOPEZ, R. J.; ABREU, J. H.; REGALADO, A. P.; HERNANDEZ, J. F. G. Riego localizado. 2. ed. Madrid: Ediciones Mundi Prensa, 1997. 405 p.

MANTOVANI, E. C. AVALIA: programa de avaliação da irrigação por aspersão e localizada. Viçosa, MG: UFV, 2001.

MARTINS, P. E. S.; SILVA, E. R.; SANTANA, V. G.; ARAÚJO NETO, J. A.; ZANINI, J. R. Uniformidade de distribuição de água do microaspersor MC-20. Revista de Ciências Agrárias, Recife, v. 38, n. 1, p. 65-70, 2015.
MARTINS, P. E. S.; ZANINI, J. R.; SILVA, E. R.; LEMOS FILHO, M. A. F. Perfil radial e uniformidade de precipitação do aspersor NaanDanJain 427, em função da regulagem do defletor. Revista Brasileira de Engenharia Agricola, Jaboticabal, v. 16, n. 1, p. 3-9, 2012.

OLIVEIRA, F. G. de; FIGUEIREDO, F. P. Influência do espaçamento entre aspersores e do uso de válvulas reguladores de pressão na uniformidade de irrigação por aspersão convencional. Revista Ceres, Viçosa, MG, v. 54, n. 316, p. 506-510, 2007.

OLIVEIRA, H. F. E. de; COLOMBO, A.; FARIA, L. C. Modelagem dos efeitos do vento sobre as dimensões do alcance do jato de um canhão hidráulico. Revista Brasileira de Engenharia Agrícola e Ambiental, Campina Grande, v. 13, p. 818-824, 2009. Suplemento 1.

PEREIRA, G. M. Aspersão convencional. In: MIRANDA, J. H.; PIRES, R. C. M. Irrigação. Piracicaba: FUNEP, 2003. v. 2, p. 703-754.

SOLOMON, K. Manufacturing variation of trickle emitters. Transactions of the ASAE, St. Joseph, v. 22, n. 5, p. 1034-1038, 1979.

ZANINI, J. R.; PAVANI, L. C.; SILVA, J. A. A. da. Irrigação em citros. Jaboticabal: Funep, 1998. 35 p. 
